\title{
What Hillary Rodham Clinton Really Said About Children's Rights and Child Policy
}

\author{
Duncan Lindscy \\ University of Toronto \\ Rosemary Sarri \\ University of Michigan
}

As editors of a professional, scientific and scholarly journal in the children's field our interest is to promote fair, careful and objective discussion of children's issues. In this regard, we have been disturbed by recent efforts to misrepresent the views and contribution of Hillary Rodham Clinton, one of our colleagues in the children's field. In this paper we systematically analyze Hillary Rodham Clinton's writings and review her contribution. Her legal approach can best be described as conservative, arguing for judicial restraint with respect to state involvement in family life. Taking into account her work on behalf of children through the Children's Defense Fund we conclude that Hillary Rodham Clinton has been an important voice for the cause of children.

First lady Nancy Reagan was a purposeful advocate for a drug-free America and targeted her message to children. Doubtless therc were critics of her approach, but she had an impact. Her sponsorship of the "Just Say No" message allowed it to sweep across the nation. Likewise, Barbara Bush has been a leading spokesperson for the cause of literacy education. Her advocacy has allowed many to overcome the historic barriers of stigmatization and guilt previously associated with adults learning to read. Although critics can be found of any advocacy effort, by and large, the efforts of these first ladies have been broadly approved.

With the recent precedents set by these two first ladies, it is surprising to observe the criticisms of the advocacy work of Hillary Rodham Clinton on behalf of children. The difference is that Hillary Rodham Clinton has advocated for these issues before entering the public eye as the wife of a presidential candidate and she has made contributions to the professional literature on children's policy in two of the most distinguished journals in the field; the Harvard Educational Review and the Yale Law Journal. These are considered among the most important professional forums in 
their field and have long traditions of upholding the highest standards of scholarship and research. Hillary Rodham Clinton did not gain access to or make her contributions to these forums as a result of her marriage to presidential aspirant Bill Clinton. Hillary Rodham Clinton published these contributions well before he was a presidential candidate.

Since Hillary Rodham Clinton established her views with published articles in distinguished professional journals, her views have become the material for review before, and not after, the presidential campaign, and thus have become the objects of often polemic and less objective political scrutiny. This is reasonable. After all, Hillary Rodham Clinton will have a voice on these issues if her husband is elected.

In the heat of a close political campaign the analysis of Hillary Rodham Clinton's views regarding children's issues have not been subjected to careful and balanced analysis and appraisal, but rather have become the source of both unfair and distorted portrayals as well as over statement and exaggeration. In this discussion we would like to examine the views of Hillary Rodham Clinton and place them within the context of current debate within the children's rights and child policy field.

Hillary Rodham Clinton has made many contributions to the professional and scholarly literature. In this discussion we will focus on her two most important contributions both because they are representative of her overall contribution and because they identify two of her most important themes- the legal rights of children and policy and programs which emerge from an understanding of the rights and responsibilities of children.

In 1973, Hillary Rodham Clinton published the lead article in an issue of the Harvard Education Review that included several papers that have now become landmark contributions. Stanford University Law Professor Robert Mnookin published his famous and frequently cited paper on legal issues surrounding foster care in this issue. In addition, Harvard University Professor Robert Light published his important paper on the incidence of child abuse and neglect.

In her article entitled, "Children Under the Law" Hillary Rodham Clinton (then known as Hillary Rodham) examined the changing status of children under the law. This paper has been widely used and frequently cited. Essentially this paper provides an examination of children's rights from a legal perspective. In fact, this paper served as the foundation for a later paper on the subject that was revised and shortened and written for the wider audience entitled, "Children's Rights: A Legal Perspective." The original paper falls into the category of traditional legal scholarship with frequent reference to previous court cases and the emergence of case law in the area. The paper does not advocate certain positions, but rather reviews the positions of others and sets them within a broader theoretical framework. The second paper provides a survey of issues surrounding 
children's rights. Although it is not as important as the first paper, and essentially derives from the first paper, it has been the work which has been targeted for criticism because the more general presentation is open to broader interpretation and misrepresentation. Consequently, we will discuss it also.

Within the framework of legal scholarship, the concerns developed by Hillary Rodham Clinton in her Harvard Educational Review article can be described as representative of one of several lines of inquiry in the area of children's rights. As Dr. William Garrison $(1984$, p. 362) has indicated, "Legal scholars have, in recent years, increasingly concerned themselves with the rights of children and adolescents" and from this work three major viewpoints on children's rights can be identified:

1) a "strong child advocacy movement (Takanashi, 1978),"

2) "the search for a definition of the child's status under the law (Rodham, 1973)," and

3) the provision for the child's "competence to participate in personal decision making (Gaylin, 1982)." (Garrison, p. 362)

The first position is representative of the recent approach taken by the United Nations in its Convention on the Rights of the Child. (The United States is alone among the developed nations not to be a signatory to the Rights of the Child.) Hillary Rodham Clinton's work, which represents the second approach, examined the search for a definition of the child's status under the law. Her focus has been to review developments in case law and child development research with respect to defining the child's status under the law. Although this topic lacks glamour and sizzle, it is fundamental to developing a foundation for child policies and programs.

Finally, the third major approach to the legal rights of children identified by Garrison concerns efforts to assess the competence of minors and their ability to participate in decision-making. Although some overlap is inevitable among all three approaches, they represent consistent themes which have emerged. Since our concern is with the views of Hillary Rodham Clinton, we will focus on the second approach as it is developed in her paper.

\section{The Child's Status Under the Law}

Under the law an adult individual has certain unalienable rights that are guaranteed by the constitution and reaffirmed in case law. But what about children? The English Common Law traditions which views children as chattel are with us in many aspects of the juvenile court and the administrative departments, especially mental health and juvenile justice. Frances Allen (1966) emphasized that the only substantive right that children have is the right to custody and that as a society we fail to recognize the 
"personhood" of children and youth. For example, children are obliged to attend school to a certain age, but they have no right to an education.

Historically the child has been seen as having limited status under the law. The interests of the child have been identified as being the same as those of his or her parent. Consequently, the child's rights were defined by the parents. When the child turned eighteen years of age then he or she attained independent legal status. Over time case law has provided children with additional rights independent of their parents and often requiring approval of the parents. For example, in custody disputes the courts have now permitted testimony by children as young as 12 years of age. Children are permitted the "right" to drive at age 16.

\section{Children's Rights and Coercive State Intervention}

After reviewing the emerging legal status of children, Hillary Rodham Clinton examines the rights of children subjected to child abuse and neglect (either physical, sexual or emotional). Hillary Rodham Clinton contrasts the two principal legal standards used to determine when the state should intervene in situations of child abuse and neglect:

1) "the best interest of the child" standard and

2) "the least detrimental alternative for the child" standard.

Examination of these standards represents the heart of her work. In her closing paragraphs Hillary Rodham Clinton writes, "Even though state interference with family privacy should be minimized because of the state's unwillingness, or inability, to care for children as well as most families do, the state, representing the community of adults, has the responsibility to intervene in cases of severe emotional deprivation or psychological damage if it is likely that a child's development will be substantially harmed by his continued presence in the family." (p. 514)

The major concern regarding state intervention in cases of child abuse and neglect is with developing adequate legal standards. Hillary Rodham Clinton observes, "This will involve specifying acceptablc rcasons for intervention and providing workable review mechanisms for the initial decision and the child's placement. Intervention should be allowed only after the state has attempted to provide services for the child and his parents aimed at ameliorating the conditions of neglect. Only medically justifiable reasons for intervention should be acceptable. Parental behavior that does not result in medically diagnoseable harm to a child should not be allowed to trigger intervention, however offensive that behavior may be to the community." (p. 514)

This represents a conservative legal position which strictly limits state intervention. It should be noted that there is no mention of children disobeying adults or suing their parents. These are issues outside the scope of 
legal standards considered by Hillary Rodham Clinton. In fact, given her emphasis on strict legal standards and limited state intervention in the family, it is unlikely that she would support an increased involvement of the courts in family life. Certainly, she rejects broad intervention into family life as would be seen as commonplace in Western European countries. Hillary Rodham Clinton's analysis of the many facets of children's status and rights is excellent and this article has been the seminal piece for many cases in the U.S. Courts.

In her second article published in an edited volume published by Teachers College Press of Columbia University, Hillary Rodham Clinton explains to a wider audience the essence of the discussion found in her legal scholarship. In this article Hillary Rodham Clinton examines four broad categories where children's relations have been covered by law:

"1. Children's rights in relation to the family

2. The rights of children without families

3. Children's rights in juvenile-oriented institutions

4. Children's rights in society" (1979, p. 22).

Looking at children's rights in the family, Hillary Rodham Clinton examines two main areas; state intervention and independent decisions by children. Examining state intervention in the lives of families Hillary Rodham Clinton continues her view of judicial restraint arguing, "What is needed is a theory that adequately explains the state's appropriate role in child rearing and provides sufficient checks on the exercise of discretion to ensure that authority is exercised only in warranted cases." (p. 23)

\section{Independent Decisions by Children}

While only a very small part of her paper, the issue of independent decision-making by children has been the focus of criticism of her work. Hillary Rodham Clinton observes, "Disagreements between children and their parents are a common occurrence and usually do not rise to the level of a legal question. However, several such disagreements have reached the courts, and a body of case law has developed around them." (p. 24) Hillary Rodham Clinton reviews these cases and their historical context. For example, she writes, "During the nineteenth century in this country, the idea of compulsory education provided an opportunity for children to be trained, and took them out of the work force, so that they would not compete with adults. Child labor laws continued this trend and so did the imposition of age requirements for school attendance." (p. 25)

Hillary Rodham Clinton then observes that because of these changes we have now come to a period when children remain in the family for a longer period, "during which they are still dependent but becoming more and more adult" and thus "the opportunities for intrafamily disputes have 
increased dramatically." (p. 25) She points out that fears about children's rights stem from "concern about increasing governmental control over such intrafamily disputes." (p. 25) She provides an illustration, "A letter sent out several years ago about the Child and Family Development Act urged persons to oppose the proposed bill because it would, according to the writers, allow children to take parents to court if they were ordered to take out the garbage." Clearly, this was a ludicrous claim. Hillary Rodham Clinton observed, "Family disagreements that result in legal battles are, of course, of a more serious nature." She points out, "There are, for instance, a line of cases in which a child either wished or required a certain medical procedure that his or her parents refused to provide. In some cases, the disagreement was between the child and parent and in others between the parent and medical experts. In both types of cases, the state often enforced a child's right to receive necessary care." (p. 25-26)

After reviewing cases involving religious objection to medical treatment, Hillary Rodham Clinton provides her own view. "Even among persons in the children's rights movement, there is a concern that extending rights to children against their parents is too difficult to control, and in all but the most extreme cases such questions should be resolved by the families, not the courts. We prefer that intervention into an ongoing family be limited to decisions that could have long-term and possibly irreparable effects if they were not resolved." (p. 26). Again, this is a conservative legal position. It is difficult to imagine someone suggesting that a parent be allowed to make decisions regarding their children which have "long term" and "irreparable effects" without any judicial intervention.

The rights presently acknowledged for children are largely procedural and instrumental, and thus, in the terms of Goodin, negative rather than positive rights. Thus, society concerns itself with the protection of children from harm in various ways, but does very little to acknowledge positive rights such as the rights to education, to child care, to health care, to a home, to ethnic identity, to be assessed in a culturally appropriate normative context. Hillary Clinton Rodham does not address this issue which would represent the mainstream liberal perspective.

In the remainder of her second article on children's rights Hillary Rodham Clinton reviews the rights of children without families (i.e., those children in foster care or group homes) and of children living in institutions. She concludes with a discussion of how these issues relate to children's policies.

\section{Children's Policies}

Concern at the federal level with children's policies has suffered from benign neglect. As Hillary Rodham Clinton $(1977$, p. 1523) wrote in The Yale Law Journal, "In a recent address to a conference on children's 
needs, a United States senator admitted he knew nothing about the subject and would have felt more comfortable discussing energy. Policymakers are simply not accustomed to thinking about children's needs in the same ways they think about missile development, dam construction, or even old-age assistance." Yet this is an area of major concern for Hillary Rodham Clinton. In the Yale Law Journal she reviewed Gilbert Steiner's (1976), The Children's Cause, a study of children's policies and programs at the federal level in the United States. She compliments the study for "treating the subject with the professional respect due serious political issues" and for "stripping away much of the sentimentality, political naivete, and excuse-making that have served as camouflage for ineffectiveness, waste, and fuzzy thinking."

There are two major child welfare policy strategies that determine specific policies and programs- universalism vs. residualism. In contrast to the approaches of many European countries and those of Canada, the predominant view in the United States has been "residual", and it is the view advocated by Steiner. The focus of this approach, according to Hillary Rodham Clinton, is to "attempt to remedy deficiencies in a particular child population" (p. 1526). [Steiner] "urges children's advocates to temper their demands, sharpen their practical political skills, and work to improve and expand existing programs for 'demonstrably unlucky children whose bodies or minds are sick or whose families are unstable or in poverty' (citing Steiner, 1976, p. 255)." The other major approach to children's policies promotes programs that "provide services for the entire child population" (p. 1526).

The limitation of the residual approach is that it requires children have problems before services are provided. It thus has the paradoxical effect of rewarding those who fail or fall behind. In contrast, the universal approach views children's policies and programs as part of the broader public infrastructure designed to nurture and develop the potential of all children. Like the public school system, public health programs, and recreational programs, children's programs should provide opportunities to all children that will allow those children to develop their full potential.

Hillary Rodham Clinton disagrees with Steiner's argument for the residual model. She writes, "There is nothing wrong with pressing for better programs for the needy, but Steiner sets his sights too low." In addition, Hillary Rodham Clinton argues for thoughtful accountability in programs. She observed in 1977, "Refinement of cstablished programs such as Head Start, may provide another avenue for experimentation in child development policy. Recent evidence indicates that Head Start is achicving not only its original purpose, namely cognitive gains, but also improvements in children's social behavior, parental attitudes, community involvement, and children's health. This successful evolution suggests that the program should be strengthened and expanded within its present 
structure with an eye to testing the comprehensive approach." (p. 1531)

After examining and discussing the compensatory and comprehensive approaches, Hillary Rodham Clinton concludes by embracing a centrist position which recognizes the role of each position. In her concluding paragraph she writes, "Steiner's failure to endorse a comprehensive approach to children's policies is disappointing. In advocating more of the same compensatory programs, Steiner fails to recognize that the compensatory and comprehensive approaches are complementary and should be pursued simultaneously." (p. 1531)

\section{The Historical Context of Hillary Rodham Clinton's Work}

The 1970s, when Hillary Rodham Clinton published the papers discussed above, were a decade of great accomplishment in the child welfare field. Major research and demonstration programs that were based on findings from research conducted in the previous decade were carried out. These federally supported research programs demonstrated the effectiveness of the "permanency planning" approach. Permanency planning was an approach that was critical of government programs that allowed children to he removed from their parents and placed in foster care, where many stayed for years with no prospects of a permanent home being planned. The hopeless lingering of hundreds of thousands of children in foster care required action. The emphasis of permanency planning was to return these children home from foster care or to to free them for adoption. In other words, the goal was to find children who had been cast adrift in foster care a permanent home.

Research conducted in Oregon, California, Tennessee and elsewhere, as well as the multiple state research of the Children's Defense Fund laid the foundation for comprehensive child welfare reform (Knitzer, Allen, \& McGowan, 1978). In 1980, Congress passed the most comprehensive legislation in decades, the Adoptions Assistance and Child Welfare Act, implementing on a federal level the findings from the permanency planning research. As a result of permanency planning, the number of children in foster care had been reduced from almost 500,000 to about half that number in less than five years. The 1980s began with hope and expectation of being a great period of progress for children (Lindsey, 1982).

\section{Recent Efforts}

Hillary Rodham Clinton has developed an understanding of these child policy issues. She has developed the theoretical base for her views in her published works. Although a centrist on children's rights, her underlying passion is found in her concern for the welfare of all children through her work on behalf of children at the Children's Defense Fund. Make no 
mistake about it, in the area of theoretical analysis and scholarship concerning child policy Hillary Rodham Clinton stands shoulder to shoulder with the most articulate theorists. Her writings place her in the center of legal thought. In fact, she has little patience with dogmatism from either the left or right. Her overwhelming commitment seems to be to make a difference for children.

Hillary Rodham Clinton made the above contributions to the professional literature more than a decade ago. What has happened since the publication of these papers? Like many women in modern America Hillary Rodham Clinton has had to balance her personal and professional life. What began with a remarkable contribution to legal scholarship at a young age has shifted to a balance between raising a family and continuing her work on behalf of children, along with trying to hold down a legal career and obtaining a partnership in a major law firm. During the last several years Hillary Rodham Clinton has served on the Board of Directors of the Children's Defense Fund, and serving as chair for several years. Under her leadership the Children's Defense Fund has become what many regard as the most important and successful nonpartisan research and advocacy organization for children in the United States.

In spite of her work with the Children's Defense Fund, the last dozen years have been quiet and uneventful in terms of progress for children. The great hope and expectation of the 1980s did not materialize. On the federal level, the last ten years have been a decade of inaction. Programs for children operated at the federal level have been slowly dismantled. 1 As the research published by the Children's Defense Fund and other children's advocacy groups have pointed out, it has been a decade of decline for children. As mentioned earlier, in 1977 it was estimated that almost 500,000 children were in foster care but that, as a result of the achievements of the permanency planning movement, the numbers had been reduced to about 250,000 in the early $1980 \mathrm{~s}$. The most recent figures indicate that the number of children in foster care has almost doubled and is now approaching 500,000 . This compares to Japan, with a population about half the size of the United States, which has less than 3,000 children

\footnotetext{
${ }^{1}$ As a result of the Adoptions Assistance and Child Welfare Act in 1980 , child welfare funding to provide for permanency planning was, according to Sheila Kamerman and Alfred Kahn of Columbia University (1990, p. 33), "to increase gradually from approximately $\$ 3$ billion in fiscal year 1981 to approximately $\$ 3.7$ billion in fiscal year 1985 . Instead, by 1985 the combined funding was less than in $1981--\$ 2.8$ billion. In contrast to the expectations for implementing the 1980 reforms, in 1981 Title XX funds were cut from $\$ 3$ billion to $\$ 2.4$ billion and so service plans for children and families are not implemented and directives from judicial and other external reviews are not followed." In 1990, Kamerman and Kahn reported on a comprehensive review of child welfare programs across the United States. They observed that the permanency planning legislation provided, "a new philosophy and a service framework. The federal government did not, however, provide the resources on which all else was premised." (1990, p. 9).
} 
in foster care. During the last dozen years the number of reports of child abuse and neglect have increased by more than 150 percent (from $1,154,000$ in 1980 to more than $2,500,000$ in 1991). The rate of child abuse and neglect reports in the United States is many times higher than any other industrialized nation in the world. The rate is more than ten times higher than Canada, just across the border and magnitudes higher than Germany, Italy, France, Japan and other industrialized countries.

As documented by the Children's Defense Fund, the number of children living in poverty in the United States stopped going down and has begun increasing (Johnson, Miranda, Sherman, \& Weill, 1991). Children now represent the single highest category of people in poverty. In the United States more than ten million children live in poverty, an increase of more than a million in the last decade. Almost five million children live in households with less than one half the poverty line income. Perhaps most staggering of all is the situation of young black children in the United States. Almost two out of every three black children born in the U.S. will be born to single unwed mothers, most of whom live in severe poverty.

Although there is widespread public concern about the overall economic decline and the recession, the situation for many children in the United States is more like a depression. If there were a children's misery index composed of the number of children growing up in poverty, plus the number of children in foster care and the number of reports for child abuse and neglect, the indicator would have more than doubled in the last decade. As the President's own commission on child abuse reported (U.S. Advisory Board of Child Abuse and Neglect, 1991, p. 47), "Child maltreatment is a serious, complex, and widespread problem that often has lasting consequences. It demands a comprehensive, high-priority response. The failure to provide such a response has led tragically to a system that is overwhelmed and on the verge of collapse- a collapse so grave that children will be even more seriously at risk than they are now, thus causing countless additional American children to suffer irreparable harm."

But the last decade has also been a calamity for all children, not just those living in poverty or reported because of abuse and neglect. During the last decade the United States has gone from the nation owed the most money to the nation owing the most money. The national debt was approximately one trillion dollars ten years ago. Now it has grown to about four trillion dollars with no foreseeable trend in the other direction. This is a debt which this generation will leave to the next. If the debt were divided and assigned to each child equally it would amount to more than $\$ 60,000$ per child. As Ross Perot, U.S. Senator Phil Gramm and others have pointed out, the issue of the national debt is fundamentally an issue of child policy.

We have an opportunity in the next decade to change our statues, policies and programs that have had such negative consequences for children, 
and in so doing we will benefit all of society. North America faces a near explosion in the growth of the aged population, especially of the very old and frail elderly. Therefore, in the 21 st century, we will need to have an adult population capable of meeting that challenge. We can have such an adult population only if we ensure the well-being of all children today.

\section{References}

Allen, F. (1966). Borderland of juvenile justice. Chicago: University of Chicago Press.

Garrison, W.T. (1984). Inpatient psychiatric treatment of the difficult child: Common practices and their ethical implications. Children and Youth Services Review, 6, 353-365.

Gaylin, W. (1982). The competence of children: No longer all or none. Journal of the American Academy of Child Psychiatry, 23, 448-452.

Johnson, C.M., Miranda, L., Sherman, A., \& Weill, J.D. (1991). Child poverty in America. Washington, DC: Children's Defense Fund.

Kamerman, S.B., \& Kahn, A.J. (1990). Social services for children, youth and families in the United States. Special issue of Children and Youth Services Review, 12, 1-184.

Knitzer, J., Allen, M.A., \& McGowan, B. (1978). Children without homes. Washington, DC: Children's Defense Fund.

Lindsey, D. (1982). Achievements for children in foster care. Social Work, 27, 491-496.

Mnookin, R.H. (1973). Foster care: In whose best interest. Harvard Educational Review, 43, 599-638.

Rodham, H. (1973). Children under the law. Harvard Educational Review, 43, 487-514.

Rodham, H. (1977). Children's policies: Ahandonment and neglect. The Yale Law Journal, 86, 1522-1531.

Rodham, H. (1979). Children's rights: A legal perspective. In P.A. Vardin \& I.N. Brody (Eds.), Children's rights: Contemporary perspectives (pp. 21-36). New York: Teachers ' College Press.

Steiner, G. (1976). The children's cause. Washington, DC: The Brookings Institution.

Takanashi, R. (1978). Childhood as a social issue: Historical roots of contemporary child advocacy movements. Journal of Social Issues, 34, 8-28.

United States Advisory Board on Child Abuse and Neglect (1991). Child abuse and neglect: Critical first steps in response to a national emergency. Washington, DC: Author. 